\title{
Action research to improve furniture value chain governance and enhance livelihoods of small-scale producers
}

\author{
Herry Purnomo 1,2, Andrew Wardell', Bayuni Shantiko', Ramadhani Achdiawan', Melati', Efi Yuliati Yovi², \\ Rachman Effendi ${ }^{3}$, and Sulthon Moh. Amin ${ }^{4}$
}

\section{Key results}

1. Small-scale furniture producers have managed to increase their value added or income thanks to better understanding of the market, training provided under the Furniture Value Chain (FVC) project, participation in trade exhibitions and use of online marketing to reach a wider market.

2. The Jepara Small-scale Furniture Producers Association (APKJ) was legally established and has been functioning well. APKJ has emerged as an effective forum for improving its members' capacity to manufacture better-quality furniture, to deal with management issues and to reduce the time to delivery.

3. A comprehensive strategy for the development of the furniture industry (the 'Roadmap') was created for the period 2013-2023 and a Jepara District Regulation has been drafted.

4. One group of small-scale furniture manufacturers and one individual applied for certification under Indonesia's national Timber Legality Assurance System (TLAS or SVLK (Sistem Verifikasi Legalitas Kayu)) and have been through the verification process. The potential for entering the emerging domestic 'green furniture' market is being explored.

5. Furniture producers have become more efficient in their use of wood and of value chains.

6. Findings from the project have been published and disseminated in multiple forms, including articles in scientific journals, books, conference papers, newsletters, a project website, media articles and local radio broadcasts.

7. The capacity of a broad range of Indonesian partners in conducting value chain analysis through action research has been developed.

\section{Hasil utama}

1. Produsen mebel skala kecil telah mengalami kenaikan nilai tambah atau penghasilan karena telah belajar memahami bagaimana pasar bekerja, mengikuti pelatihan-pelatihan yang diselenggarakan oleh proyek FVC, pameran perdagangan dan pemasaran online sehingga mereka menjangkau pasar yang lebih luas.

2. Asosiasi pengrajin kecil Jepara (APKJ) terbentuk dan disahkan melalui notaris dan berjalan secara baik. APKJ menjadi forum yang efektif untuk meningkatkan kapasitas produsen mebel, mengatasi permasalahan anggota dan mengirim pesanan secara tepat waktu.

3. Strategi komprehensif untuk pengembangan industri mebel (Roadmap industri mebel) telah dibuat untuk periode 2013-2023 dan akan menjadi naskah rancangan peraturan daerah (ranPERDA).

4. Kelompok produsen mebel skala kecil dan produsen individu berhasil menjalani proses verifikasi SVLK untuk mendapatkan sertifikat. Potensi munculnya pasar industri mebel hijau didalam negeri juga diteliti.

5. Efisiensi penggunaan kayu dan rantai nilai mebel dari produsen telah meningkat.

6. Sejumlah publikasi meliputi jurnal ilmiah, buku, makalah konferensi, newsletter, website proyek, artikel popular dan siaran di tingkat radio lokal dibuat dan disebarluaskan.

7. Sejumlah mitra proyek mendapatkan peningkatan kapasitas untuk melakukan analisis rantai nilai dan riset aksi. 


\section{Context}

The international trade in furniture is of great value to manufacturing countries such as Indonesia, whose annual furniture exports were valued at US\$1.4 billion in 2012. World furniture production has been growing at an average of $8 \%$ a year during the past decade. Furniture-making is one of the most labour-intensive industries in the forestry sector, and, particularly in developing countries, is mainly comprised of small and medium enterprises (SMEs). The health of the industry is therefore important for efforts to alleviate poverty and reduce unemployment.

Furniture-making is central to the history and culture of Jepara, a district in Central Java, Indonesia. About one-third of the furniture made in Central Java comes from Jepara, which has about 12000 business units (Figure 1) and processes an estimated 900000 cubic metres of wood each year. Jepara's long tradition of making high-quality furniture has been possible thanks to the region's access to premiumquality teak. The furniture industry contributes about $27 \%$ of the district's economy. Annual exports of Jepara furniture in 2012 were valued at US\$110 million. However, although the overall value added is very high, it is unevenly distributed among the actors in the value chain: large finishing and exporting companies take a greater proportion of the added value than either small-scale furniture producers or tree growers.

\section{The research project and ACIAR initiative}

The research project titled 'Mahogany and teak furniture: action research to improve value chain efficiency and

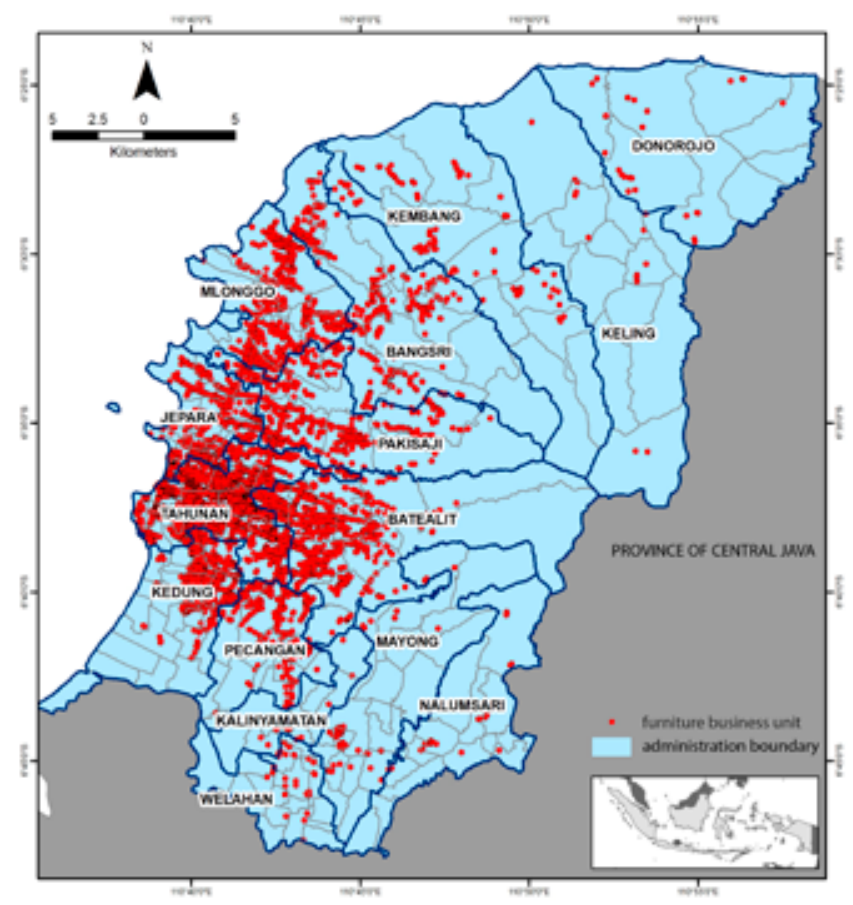

Figure 1. Distribution of furniture business units in Jepara (inset: in all of Indonesia) enhance livelihoods' (hereinafter, the Furniture Value Chain or FVC project) was funded by the Australian Centre for International Agricultural Research (ACIAR) and ran from 2008 to 2013 (Ref: FST/2007/119). The objectives of the project were (1) to enhance the structure and functioning of the furniture industry to benefit small-scale producers and (2) to improve marketing by small-scale furniture producers and their organisation(s). The project adopted value chain analysis and participatory action research methods to achieve these objectives. A furniture value chain tracks the value added to timber as it moves from growers to furniture makers to the market. A key element of the participatory action research was the selection of local actors, so-called 'champions', who had the knowledge and capacity to articulate their problems, needs and possible solutions.

This research was carried out in collaboration with the Forestry Research and Development Agency of Indonesia's Ministry of Forestry, the Faculty of Forestry of Bogor Agricultural University, Jepara District Government and the University of Melbourne. The research project formed part of ACIAR's forestry programme, which aims to contribute to poverty alleviation and natural resource conservation and rehabilitation. In particular, the project was connected to ACIAR's annual operational plan 2010-2011 for improved forest governance and administration through action research at provincial and district levels, application of improved silvicultural strategies and governance arrangements, capture of more value from forestry plantation species, development of new products matched to appropriate markets, understanding of incentives for small communities and analysis of systems and markets that provide intermediate returns for smallholder farmers.

The project worked closely with another ACIAR project in Jepara, titled 'Improving added value and small medium enterprises capacity in the utilisation of plantation timber for furniture production in Jepara region' (Ref. FST/2006/117).

\section{Value chain governance}

The FVC project found that small-scale furniture producers and domestic brokers are in a directed network, as indicated by the following features: producers' main customers buy at least $50 \%$ of their output; their customers define products and provide technical assistance; and access to market information is asymmetrical (Figure 2). Brokers can easily leave one furniture maker and shift to another. Similarly, governance between exporters and small-scale furniture makers is also of the directed network type. In some cases, the relationship becomes hierarchical, that is, exporters exert greater control over small-scale furniture makers, as indicated by vertical integration or by the producers' very limited autonomy in decision-making. Producers of machine-made furniture have a better position in the value chain: they are in a balanced network with actors at higher stages of the chain, namely global brokers and importers, as indicated by the following features: the supplier has a 


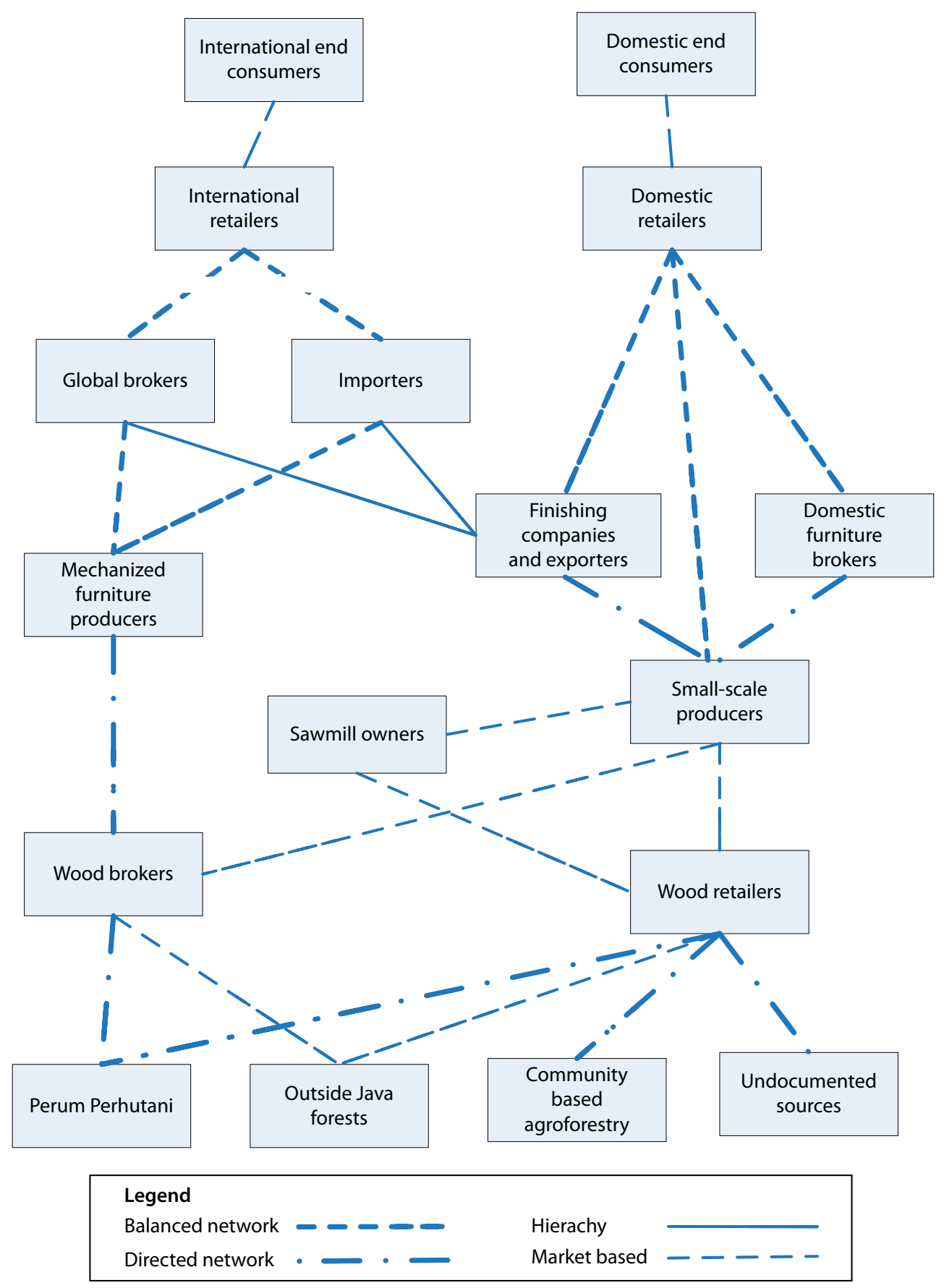

Figure 2. Governance relationships between actors in the furniture value chain

range of customers; there is intensive information flow in both directions; and both sides have the capacity and commitment to solve problems through negotiation. Relationships between small-scale furniture makers and sawmill owners and wood retailers are market based, as indicated by the large numbers of both customers and suppliers, where nobody controls transactions or prices, and small-scale furniture producers can freely buy wood from suppliers.
The results of surveys and the value chain analysis were used to construct four scenarios: 'moving up', 'collaborating down', 'small-scale associations' and 'green furniture'. These scenarios are strategic ways to improve the furniture industry in Jepara for the benefit of small-scale furniture makers. The 'moving up'scenario encourages small-scale producers to move up in the value chain because, in a buyer-driven value chain, actors at higher levels generally exert control over those at lower levels. The 'collaborating down'scenario urges small- 
scale furniture makers to collaborate with wood traders and tree growers to secure sustainably grown wood supplies. The 'small-scale association' scenario suggests forming local organisations of small enterprises, which can then provide assistance in accessing credit through financial institutions and in improving access to established and/or new markets. The 'green furniture' scenario considers the production of certified, eco-labelled or'green'furniture, which requires vertical and horizontal coordination between companies in the value chain. The FVC project worked primarily at the policy level to help strengthen the future position of smallscale furniture manufacturers.

\section{Outcomes}

\section{Social}

The FVC project supported the establishment of the APKJ (Jepara Small-scale Furniture Producers Association) as part of the 'small-scale association' scenario. As of April 2009, 60 small-scale producers had joined APKJ, and more followed. APKJ has improved cohesion among small-scale furniture producers and acts as a forum where they can interact, broaden their influence and set targets. APKJ has been able to negotiate with other associations in Jepara such as the Indonesian Furniture Industry and Handicrafts Association (ASMINDO) and the Jepara Wood Traders Association. The Jepara District Head has acknowledged the important role of APKJ.

The establishment of APKJ has led to increased networking among small-scale furniture producers and has given them a stronger voice in social and political arenas in Jepara. APKJ and its members have been invited to and involved in many discussions on Jepara furniture, and local college students have conducted internships through the association. In the political arena, the local government has relied on APKJ to represent small-scale furniture producers in business and policy events. The local government has also recognised the association's valuable role in organising its members. For example, during the Jepara Expo in 2010 and 2011, the Jepara Government provided exhibition stands for ASMINDO and APKJ of the same size. APKJ also opened communication channels between small-scale furniture makers and the Ministries of Trade, Industry and Forestry, as well as with organisations under these ministries at various levels. The institutional innovation that characterises APKJ has been shared with all furniture stakeholders at local and national levels. Indeed, APKJ has become an example of how small-scale producers can improve through organisation, as recognised by the Presidential Work Unit on Overseeing and Controlling Development.

\section{Economic}

Members of APKJ stated that since joining APKJ they have been exposed to greater opportunities either through improved market access or through the adoption of innovations, such as the use of an Internet portal to market their furniture. Half of the APKJ champions accessed loans from BRI (Bank Rakyat Indonesia) after participating in a financial training course run under the FVC project. Loans granted were in the range of 10 million - 50 million Indonesian rupiah (US\$1 is approximately equal to 9600 rupiah).

In particular, the 120 members of APKJ have noticed economic outcomes related to the project and the association. An impact assessment that compared the performance of members and non-members found that more members were improving in several aspects of their business. In total production, sales and profits, more than $85 \%$ of APKJ members had seen improvements in the 5 years before the study, compared with only $60-74 \%$ of non-members. This suggests that membership in APKJ has been beneficial for most aspects of furniture production (Figure 3).

\section{Policy}

Under the FVC project, a strategic plan for the furniture industry in Jepara was created. This plan, titled 'A roadmap for the furniture industry 2013-2023', is designed to guide the development of the furniture industry in Jepara. Bappeda (Jepara Government Planning Agency), ASMINDO, KADIN (Jepara Chambers of Commerce \& Industry), ASEPHI (Association of Exporters and Producers of Indonesian Handicrafts), Jepara government agencies, Jepara Nahdlatul Ulama Design College, Jepara Nahdlatul Ulama Economics College and APKJ were the main partners for this work.

During discussions with the Head of Jepara District (Bupati) and a large number of stakeholders, two options for the adoption of the roadmap emerged: that it be formalised either as a Bupati regulation (PERBUP) or as a district regulation (PERDA). After a series of meetings, the option of proposing a PERDA was selected to ensure the plan

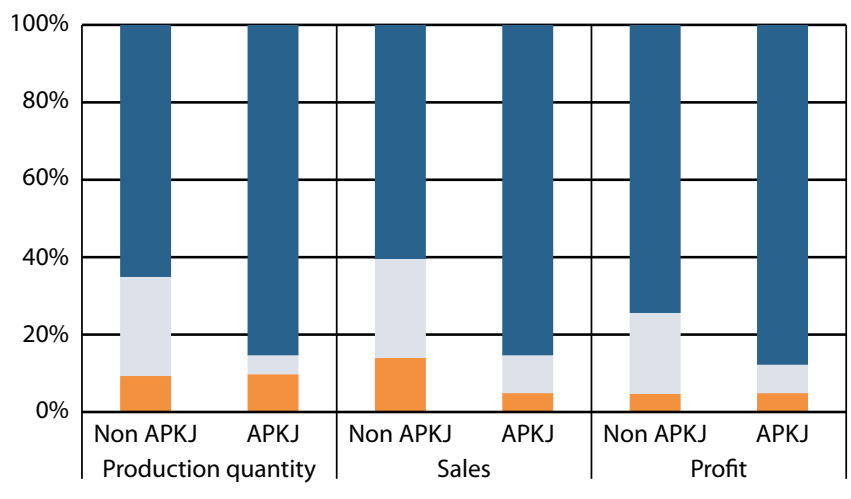

Decreasing Stable $\square$ Increasing

Figure 3. Changes in furniture businesses in the previous 5 years (2007-2012) 


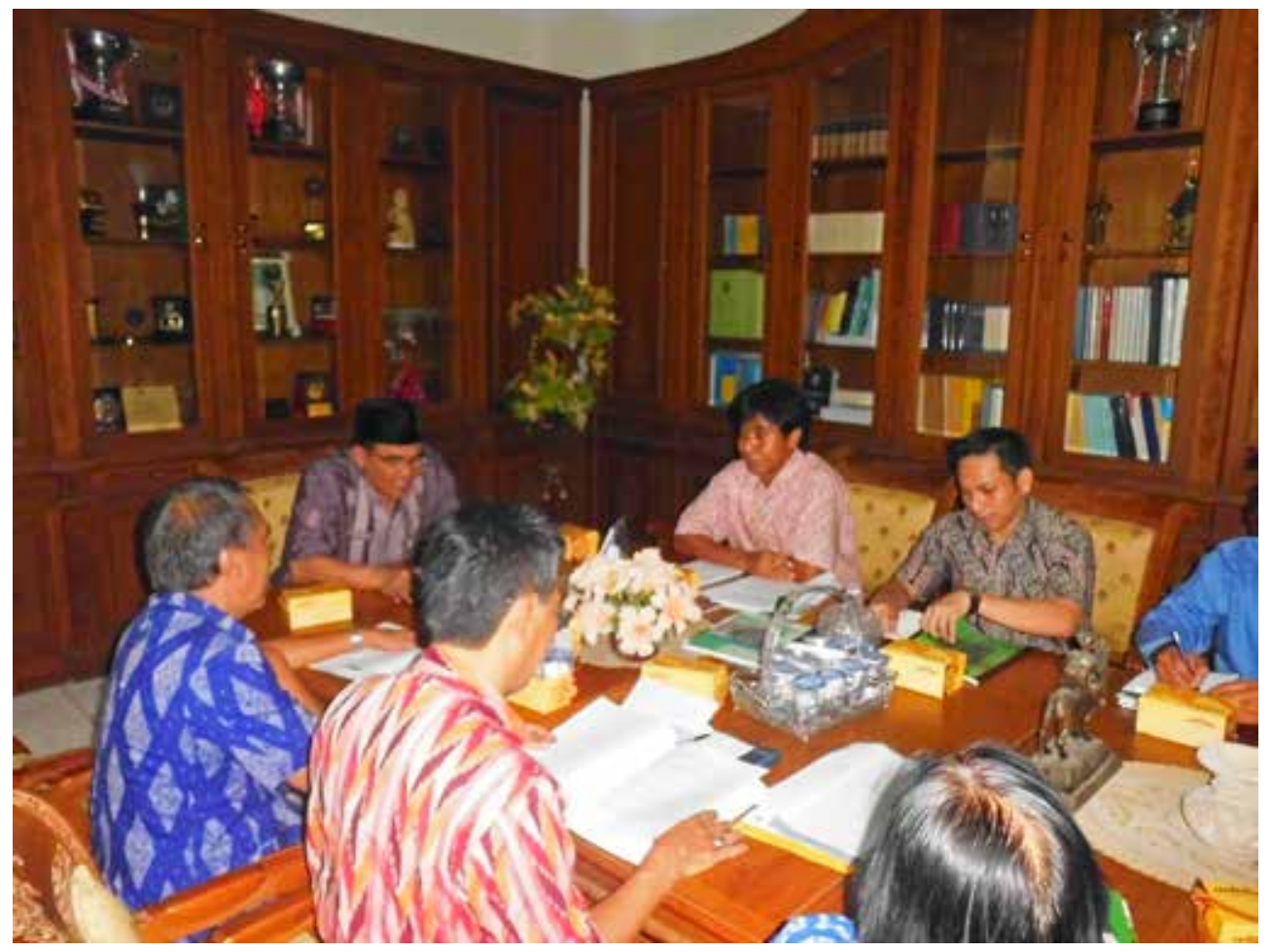

Sharing the roadmap with the Jepara head of district government (Bupati) created a roadmap with improvements and endorsements. Photo by Sulthon.

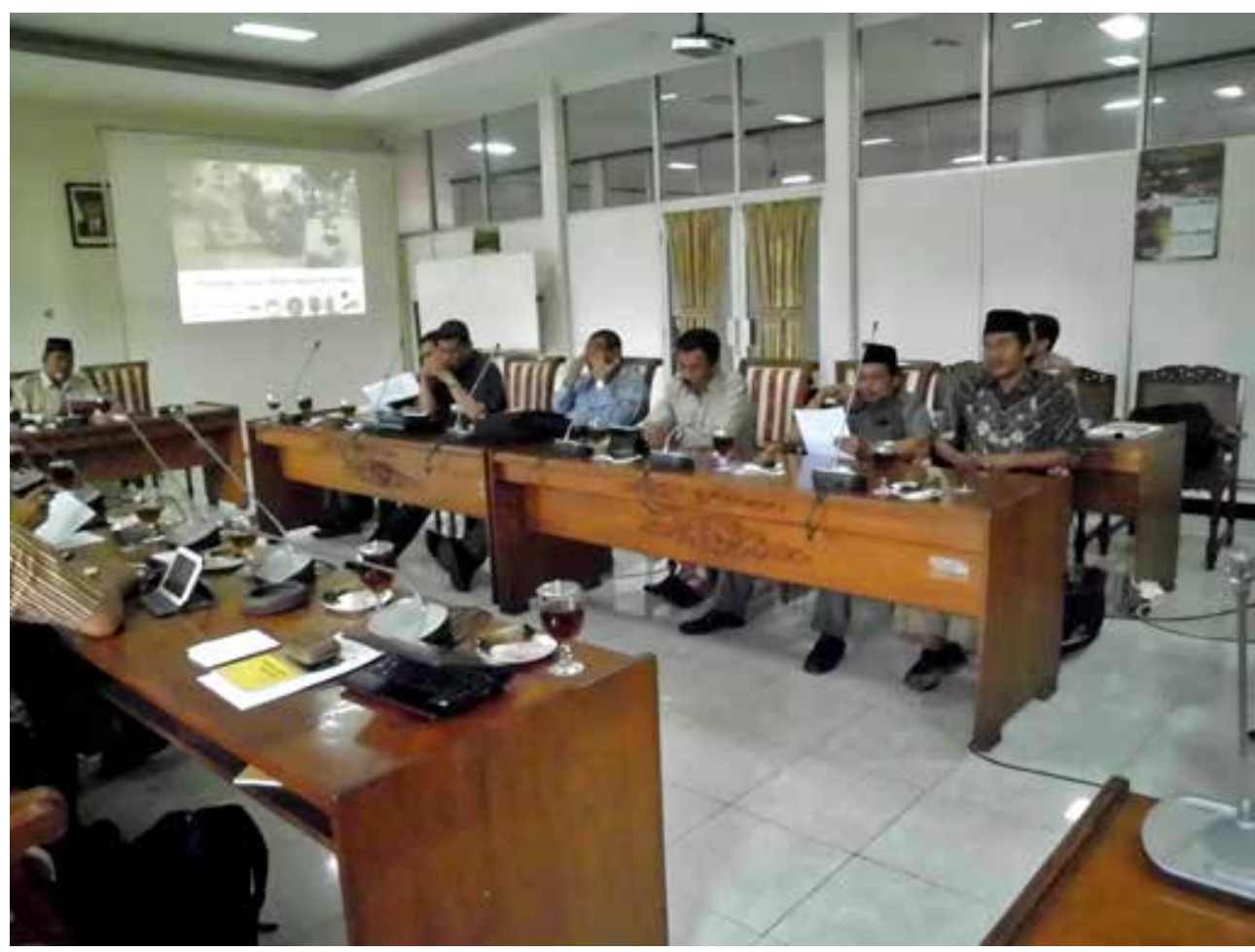

A hearing with the district parliament members who amended the roadmap, resulting in the local parliament initiative to be submitted as a district regulation (PERDA). Photo by Sulthon. 
( =

carried more weight and would have a longer enforcement period. The hearings between the FVC project team and the Jepara parliament resulted in the following five conclusions: (1) on behalf of the people of Jepara, the Parliament expressed its appreciation and gratitude to CIFOR and ACIAR for their research in Jepara, which had been recorded in the roadmap for the Jepara furniture industry 2013-2023; (2) the Parliament requested the local government to follow up on recommendations in the roadmap and discuss them with local stakeholders; (3) the Chair of the House of Parliament gave a mandate to Commission B to discuss the recommendations in the roadmap with the local government; (4) the Parliament agreed to formalise the roadmap as a House Initiative District Regulation in 2013 (PERDA Inisiatif); and (5) the Parliament requested that the local government interpret and incorporate action plans detailed in the roadmap into the local government agenda.

\section{Environment}

As part of the 'green furniture' scenario, small-scale furniture makers were educated about certification and encouraged to enter the certification market with either voluntary or mandatory certification. In collaboration with the Center for Indonesia's Export Development (or Pusat Pengembangan Ekspor Indonesia; PPEI), the FVC project opened communication channels with the Ministry of Trade. PPEI developed training on the voluntary chain of custody scheme for small-scale producers, which has benefited APKJ members. The Government of Indonesia is promoting its new mandatory Timber Legality Assurance System (TLAS), and the Multistakeholder Forestry Programme of the UK Department for International Development is facilitating the training of APKJ members in TLAS compliance. About 10 members of APKJ participated in a trial group application and one member applied for TLAS certification as an individual (Box 1). The individual successfully met TLAS compliance requirements and was invited to London to share his experiences of the process. APKJ's group application has been reviewed by TLAS assessors, and the group is awaiting the results.

APKJ members' efficiency in the use of wood improved by approximately $10-15 \%$, following training in areas such as product design, finishing and marketing. The introduction of better sanding and finishing practices has also attributed to improvements in wood efficiency. Better marketing has helped manufacturers create more value added for the same amount of wood, which helps conserve forests and increase their value. In addition, APKJ members who own unproductive land have begun planting clone teak. The FVC project also developed occupational health and safety guidelines for the Jepara furniture industry, which have been submitted to members of Jepara's parliament for review.

\section{Box 1. How an individual small-scale furniture maker obtained TLAS certification}

Abdul Latif, the son of farmers in Sinanggul village in Mlonggo, Jepara, has been working in the furniture industry since he graduated from high school about 16 years ago. He recalls that the first product he ever made was a Marlborough bench and stackable chairs. A graduate from a language academy with a major in English, Mr Latif now owns and manages a small furniture-making workshop in his hometown. His business, CV Mebel Jati Jepara, officially opened on 13 October 2011. He has 10 regular employees, and takes on up to 60 employees when orders are at their peak. His main orders now come from Europe, especially France.

Mr Latif joined the Jepara Small-scale Furniture Producers Association (APKJ) in 2010, which was initiated as part of the Furniture Value Chain (FVC) project run by CIFOR and supported by ACIAR. Through his participation in this association, he has been able to broaden his network and increase his access to market information. APKJ sought to build the capacity of Jepara's small-scale furniture makers by conducting training in various areas, including business management and online marketing. His involvement with APKJ also exposed Mr Latif to the Indonesian government's Timber Legality Assurance System (TLAS) and its implementing regulation.

To comply with the requirements of this new regulation, Mr Latif kept records of his suppliers' business documents and his company's transactions. In 2011, he began learning about TLAS, as part of his membership in APKJ, which, in 2012 received technical assistance from the Multistakeholder Forestry Programme (MFP-DfID) to apply for legality certificates based on compliance with the TLAS. Although some APKJ members were applying as a group, Mr Latif elected to make an individual application. His company was granted a legality certificate under the TLAS on 4 April 2013, making him the first small-scale furniture producer to achieve compliance. The process was difficult, he reported, because of the number of criteria and his unfamiliarity with the system. Usually, small-scale furniture producers do not record their business transactions because of poor management practices and the multiple tasks that owners must perform. The TLAS compliance process taught him that business administration is as important as meeting deadlines for orders, and he has since recruited a manager. 


\section{Capacity building}

The research enhanced the capacity of Indonesian partners in conducting action research using value chain analyses. These partners include students from Jepara NU Design College, Jepara NU Economics College and Bogor Agricultural University, as well as small-scale furniture makers. Other individuals, all of whom were trained by researchers, were involved in conducting the surveys on livelihoods, business units, markets, timber supply and the value chain. The experience they gained improved their capacity to conduct surveys, deal with a range of people and understand the furniture industry in Jepara.

Local people were involved, both individually and as groups, in writing the three books published as part of the project. For all of them, the book was their first writing experience, and they gained new skills in expressing themselves and writing about their own experiences. In addition, several PhD students researched topics related to furniture value chains and three undergraduates from Bogor Agricultural University are conducting research in Jepara, with the support of the project. In addition, the project created internships for master's students from national and foreign universities to conduct research; all these students have received their degrees and shared their theses with the project.

Two furniture makers from Jepara went to India, with the assistance of the project, in November 2011, where they presented APKJ and promoted their products to the International Wood Culture Society. They received an order for a carved dragon valued at 100 million rupiah and further orders from China. The money was used to establish CV Indonesia Furniture Center in Mulyoharjo village in Jepara.

The project is continuing to build the capacity of APKJ so that it can be self-sufficient. This includes supporting the development of a cooperative as a commercial arm of the association. The cooperative will manage the daily operation of the association's marketing portal (www.javamebel.com).

The project has also helped redress the gender imbalance among APKJ members by providing training programmes tailored to women in collaboration with IWAPI, a women's business organisation.

\section{Outputs and communication activities}

The FVC project integrated research, extension and capacity building. Through surveys, value chain analysis, action research, market research and political economy research, both researchers and local champions gained a deeper overall understanding of the problems in the industry, which made them better able to identify opportunities to solve those problems. Throughout this process, champions and their associates received extension services, such as seminars, site visits, dialogues, media campaigns such as local radio broadcasts and leaflets, as appropriate. Capacity building in communications included the training of local champions, the development and maintenance of an interactive website and workshops.

Researchers involved in the FVC project participated in national and international conferences and published books, journal articles and newsletters in English and Indonesian. The project team also used the local radio programme 'Swara Jepara' to inform listeners in Jepara about the project's outputs. All project publications are available on the project's website (http://www.cifor.org/furniture) and a select list of additional reading material is provided at the end of this InfoBrief.

\section{Recommendations}

- Apply lessons learned from the formation of the Jepara Small-scale Furniture Producers Association (APKJ) to other centres for forest-product manufacturing in Indonesia, such as Pasuruan, East Java, and Cirebon, West Java.

- $\quad$ Expand the Jepara experience to work with furniture producers in other ASEAN countries, such as Vietnam, Thailand and Cambodia.

- $\quad$ Conduct further research to understand the costs and benefits of certification and timber legality, particularly for small-scale furniture manufacturers.

- Conduct additional research on 'green buyer behaviour' to better understand the opportunities to develop domestic and international 'green furniture' markets

- Stimulate policy and institutional innovations at all levels to generate opportunities for SMEs. These may include additional efforts to improve access to credit and/or subsidies to protect and support SMEs.

\section{Further reading}

Fauzan, A.U. and Purnomo, H. 2012. Uncovering the complexity: an essay on the benefits of the value chain approach to global crisis studies - a case study from Jepara, Indonesia. In: Suter, C. and Herkenrath, M. (eds). World Society in the Global Economic Crisis, 149-169. Lit Verlag, Munster, Germany.

Irawati, R.H. and Purnomo, H. (eds). 2012. Pelangi di tanah Kartini: kisah aktor mebel Jepara bertahan dan melangkah ke depan [Rainbow in Kartini's land: the survival and future of Jepara's furniture actors]. CIFOR, Bogor, Indonesia.

Melati, Irawati, R.H. and Purnomo, H. 2010. Upgrading woodbased industries: harnessing the social network of smallscale furniture producers and their institutions. Tropical Forest Management XVI(1):10-17.

Puntodewo, A., Achdiawan, R., Melati, Irawati, R.H. and Purnomo, H. 2012. Jepara furniture tourism and shopping guide. CIFOR, Bogor, Indonesia. 
Purnomo, H., Guizol, P. and Muhtaman, D.R. 2009. Governing the teak furniture business: a global value chain system dynamic modelling approach. Environmental Modelling and Software 24(12):1391-1401.

Purnomo, H., Irawati, R.H., Fauzan, A.U. and Melati. 2011. Scenario-based actions to upgrade small-scale furniture producers and their impacts on women in Central Java, Indonesia. International Forestry Review 13(2):152-162.

Purnomo, H., Irawati, R.H. and Melati (eds). 2010.

Menunggang badai: untaian kehidupan, tradisi dan kreasi aktor mebel Jepara [Riding the storm: the life, tradition and creation of Jepara furniture actors]. CIFOR, Bogor, Indonesia.
Purnomo, H., Irawati, R.H. and Wulandari, R. 2011. Kesiapan produsen mebel di Jepara dalam menghadapi sertifikasi ekolabel [Readiness of Jepara furniture manufacturers in dealing with ecolabelling certification]. Tropical Forest Management XIII(3):127-134.

Purnomo, H., Melati and Irawati, R.H. 2009. Furniture and people: a photo journey from market to forest. CIFOR, Bogor, Indonesia.

Shackleton, S., Paumgarten, F., Kassa, H., Husselman, M., Zida, M., Purnomo, H., Irawati, R.H., Fauzan, A.U. and Melati. 2012. Gender and value chains. Infobrief No 49. CIFOR, Bogor, Indonesia. Agroforestry (CRP-FTA). This collaborative program aims to enhance the management and use of forests, Forests, Trees and agroforestry and tree genetic resources across the landscape from forests to farms. CIFOR leads CRP-FTA in Agroforestry and partnership with Bioversity International, CIRAD, the International Center for Tropical Agriculture and the World Agroforestry Centre.
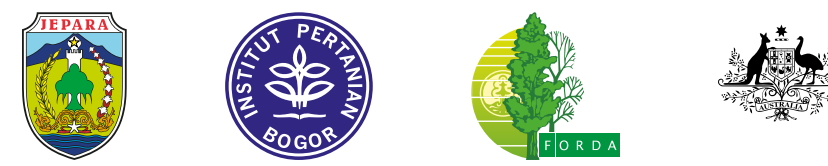